\title{
AS SOCIEDADES HISTÓRICAS NA ITÁLIA
}

Até o século XIX não havia ainda aparecido na Itália nenhum institutó público que tivesse por objeto o estudo da história medieval e moderna.

A escola histórica romântica tentara fundir a filosofia com a erudição, isto é, unir Vico e Muratori. Pouco a pouco a figura de Vico foi desaparecendo, sobressaindo a de Muratori; o espírito filosófico foi-se enfraquecendo, deixando à erudição um império quase absoluto.

A emprêsa muratoriana conseguira bom êxito devido à generosidade de particulares. As academias acolhiam alguns estudos históricos excepcionalmente, preferindo os de arqueologia ou literários.

O primeiro instituto nasceu no Piemonte. O govêrno provisório de 1799 fundou uma Deputação encarregada de recolher os documentos para uma compilação de uma história verdadeira e exata do Piemonte. Essa orientação correspondia a dois conceitos dominantes: que a história escrita até então tinha por norma uma história áulica e superficial; que para escrever uma de caráter verídico era necessário remontar às fontes e às pesquisas diretas sôbre antigas crônicas e documentos de arquivo. Devido a vários acontecimentos que sucederam nos primeiros anos do século a obra dessa comissão foi quase nula. Ela própria desapareceu, pois que a monarquia restaurada desfez tudo quanto tinha feito na sua ausência.

Mais tarde o plano do govêrno provisório foi retomado e a Deputação ressurgiu, continuando com o mesmo método: pesquisas e publicações de fontes históricas, que começam a aparecer na coleção Historiae patriae monumenta.

Por muitos anos a Deputação permaneceu como a única instituição oficial de estudos históricos na península itálica, com finalidade estritamente regional de estudos.

Com um plano mais amplo e complexo, um grupo de estudiosos toscanos, auxiliados pela mente diretora e pelo bolso de um editor inteligente, corajoso e de muito boa vontade, Gian Pietro Vieusseux, deu vida (4 de março de 1842) ao Arquivo Histórico Italiano, data essa memorável para os estudiosos da história na Itália. 
O Arquivo, por mais de vinte anos foi o único periódico italiano de estuđos históricos. Incomparável foi a eficácia dêsses estudos por meio dos quais ressurgiu e formou-se a consciência da nação.

Vieusseux escrevia a Paravia: "será um monumento erigido à pátria comum". E Capponi convidava para colaborarem Balbo, Litta, Troya (um piemontês, um lombardo, um napolitano).

O Arquivo Histórico Italiano também era destinado a publicação de documentos.

Após agôsto de 1842, Vieusseux começou a fazer aparecer modestos Apêndices onde se liam notícias sôbre a atividade das sociedades eruditas italianas, recensões, anúncios, bibliografias è memórias.

Os Apêndices, tolerados pela censura, foram alcançando sempre maior importância, colorindo assim o primitivo plano da revista.

Em 1855 Arquivo e Apêndices fundiram-se; contendo cada fascículo, document'os, memórias, resenhas, anúncios bibliográficos e notícias.

A vida do Arquivo nem sempre foi serens. As contribuições em dinheiro não eram suficientes para manter as grandes despesas. A custa de abnegação e de muita habilidade do editor, êste conseguiu mantê-lo no lugar conquistado até depois da união da Toscana ao Reino da Itália.

O grupo dos colaboradores toscanos sustentou o caráter nacional, coligando estudiosos das outras regiões. Até um alemão, Alfredo Reumont, por meio de resenhas e revistas foi uma das ligações através dos Alpes.

O impulso para as associações históricas, foi sentido também em outras regiões. Quase sem resultado foram as tentativas feitas em Nápoles por Troya, para a constituição de uma sociedade histórica que se propunha a continuar a obra de Boronio, de Muratori, de Tiraboschi', e de publicar em primeira mão o Código diplomático longobardo do próprio Troya.

Após a guerra de 1859 e das anexações, as instituições estaduais foram se multiplicando à medida que cada região da Itália se unia ao Reino.

O fervor de trabalho foi in:'enso. Cada uma das Deputações ajudou a publicar fontes narrativas, legislativas, diplomáticas; a recolher os resultados das pesquisas nos seus Atti ou no seu Arquivo Histórico (Romano, Napoli'ano, Lombardo, Siciliano, etc), modelado sôbre o Arquivo Hìtórico Italiano.

Logo apareceram dois inconvenientes: as dificuldades de dinheiro e de trabalho para formar uma coleção, que como a admirável obra muratoriana, compreendesse tôdas as fontes de história nacional podendo sustentar o confronto, sobretudo com o Monumenta Germaniae historica; e a incompatibilidade entre as várias sociedades para obter maiores resultados com menores esforços. 
Foram sugeridos dois meios: a intervenção do Estado e a ligação direta dos estudiosos, isto é, o Instituto Histórico e os Congressos nacionais.

Depois de vários anos de acaloradas discussões fundou-se o Instituto Histórico Italiano (25 de novembro de 1883) constituido pelos representantes das seis deputações e das cinco sociedades (mais tarde dez) e dos quatro membros de nomeação governamental.

Três deveriam ter sido as finalidades: 1) traçar um plano comum de esiudos e de investigações afim de coordenar esforços, promover mútua troca de notícias e diretrizes, encorajar úteis iniciativas; 2) diter normas exatas do método a seguir nas pesquisas e nas publicações; 3 ) estampar as fontes de his ória medieval e de interêsse nacional.

A primeira das finalidades não alcançou o objetivo; a segunda alcançou em parte; a terceira foi alcançada completamente.

O Instituto influiu pelo exemplo. O trabalho crítico feito pelos seus colaboradores sôbre as fontes, e o método com que foram publicadas exerceu benéfica influência. No conjunto a publicação é excelente e sustenta a comparação de qualquer outra das mais célebres entre as estrangeiras.

Juntamente com a série das Fontes, o Instituto publica: um Boletim que dá lugar aos textos menores e as relações sôbre pesquisas e trabalhos de preparação dos textos publicados ou por publicar nas Fcrntes; e os Regasta Chartarum Italiae, série destinada a satisfazer um voto do congresso histórico internacional de Roma de 1903, e que, iniciada em 1907 de acôrdo com o Instituto histórico prussiano, tornou-se na realidade quase exciusivamente italiana, devido a serem italianos onze dos treze volumes publicados.

Se no escopo de unificar a operosidade das associações faliu a obra do Instituto, não muito valeu aquela dos congressos nacionais. Desde 1879 houve seis congressos. Não faltaram as acaloradas discussões sôbre os melhores e mais interessantes assuntos. 0 resultado foi manifestar boas intenções. Talvez as únicas vantagens foram: a aproximação pessoal dos estudiosos e uma mais larga difusão de interêsse aos estudos nos mais longínquos recantos da I.ália.

De fato, naquele período as sociedades históricas foram se multiplicando rápidamente. Cada uma iniciou as suas coletâneas e o seu periódico. Foi um dilúvio de monografias, de artigos. Algumas deram provas de uma grande energia e de uma vitalidade excepcional. Entre tôdas bastará mencionar a Sociedade Histórica Subalpina que, pelo ardor incansável do fundador, Ferdinando $\mathrm{Ga}$ botto, em 25 anos publicou mais de 20 volumes de Boletins e mais de 90 volumes da sua Biblioteca; e a Comissão de Terra de Bari que publicou 8 volumes do Código diplomático barese. 
Não houve recanto da Itália que não tivesse os seus pesquisadores.

$O$ fato de ter Leão XIII aberto naquele ano o Arquivo do Vaticano contribuiu para aumentar o fervor.

Importantes foram também as iniciativas de particulares, sobretudo a reedição dos Rerum italicarum scriptores de L. A. Muratori. Batisada por Giosué Carducci, dirigida com habilidade por Vittorio Fiorini, desde 1901 já está enriquecida por diversos fascículos, contendo mais de cem páginas cada um. Pertencem ao autor dêste artigo os fascículos 85-105-153-154. Em conjunto, essas sociedade podem ser consideradas com admiração e orgulho.

Ao findar-se o século XIX o trabalho já feito era enorme. Cumpre destacar que os professôres universitários influiram grandemente para que êsse importante trabalho fôsse levado a cabo.

\section{FRANCISCO ISOLDI}

S6cio do Instituto Histórico e Geográfico de Säo Paulo.

Sócio Correspondente da " $\mathbf{R}$. Deputazione Romana di Storia Patria". Colaborador de Sociedade Muratoriana, diigida por Carducei e Fiorinl. 